\title{
DAS KONTINUUM
}

\author{
Kritische Untersuchungen \\ über die Grundlagen der Analysis
}

von

\section{Dr. Hermann Weyl}

Professor der Mathematik a. d. Eidgen.

Technischen Hochschule Zürich

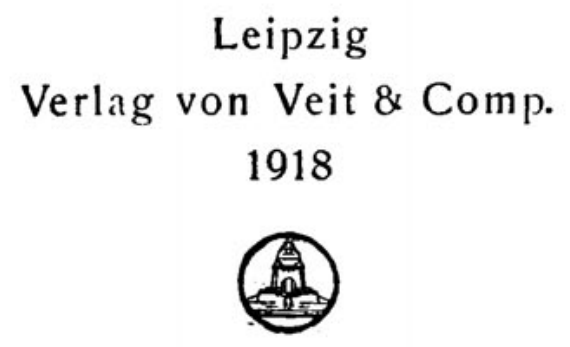


Bruck von Metrger of Wittig in Teiprzig. 